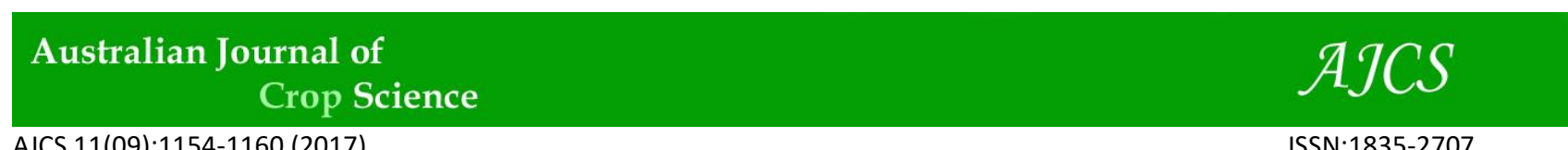

AJCS 11(09):1154-1160 (2017)

ISSN:1835-2707

doi: 10.21475/ajcs.17.11.09.pne715

\title{
Agronomic effectiveness of rhizobia strains on cowpea in two consecutive years
}

\section{Gustavo Ribeiro Xavier ${ }^{1}$, Norma Gouvêa Runjanek ${ }^{1}$, Carolina Etienne de Rosália e Silva Santos ${ }^{2}$, Ana Dolores Santiago de Freitas ${ }^{2}$, Vinicius Santos Gomes da Silva ${ }^{2 *}$, Aleksandro Ferreira da Silva ${ }^{2}$, Juscélia da Silva Ferreira ${ }^{2}$, Newton Pereira Stamford ${ }^{2}$, Lindete Míria Vieira Martins ${ }^{3}$, Jakson Leite ${ }^{4}$, Luiz Balbino Morgado ${ }^{5}$, Rosa Maria Cardoso Mota de Alcantara ${ }^{6}$}

\author{
${ }^{1}$ Embrapa Agrobiologia, Rodovia BR-465, Km 7. 23891-000, Seropédica, Rio de Janeiro, Brazil \\ ${ }^{2}$ Departamento de Agronomia, Universidade Federal Rural de Pernambuco. 52171-900, Recife, Pernambuco, \\ Brazil \\ ${ }^{3}$ Departamento de Tecnologia e Ciências Sociais Universidade do Estado da Bahia.Av. Edgard Chastinet, S/N, \\ São Geraldo, 48900-000, Juazeiro, Bahia, Brazil \\ ${ }^{4}$ Universidade Federal de Alagoas, Campus Arapiraca, Av. Manoel Severino Barbosa, Bom Sucesso, 57309-005, \\ Arapiraca, Alagoas, Brazil \\ ${ }^{5}$ Embrapa Semiárido, Rodovia BR-428, Km 152, 56302-970, Petrolina, Pernambuco, Brazil \\ ${ }^{6}$ Embrapa Meio Norte, Av. Duque de Caxias, n 5.650, 64006-220, Teresina, Piauí, Brazil
}

*Corresponding author: vinicius.agro2008.1@gmail.com

\begin{abstract}
Cowpea (Vigna unguiculata L Walp) is a legume of great social and economic importance in tropical regions. The plant is tolerant to soil and climatic adversity, while it has high nutritional value with high protein, minerals and vitamins contents. The cowpea legume has a very high ability to fix $\mathrm{N}_{2}$ which is important because it can reduce the costs of soluble mineral fertilizers and may contribute to sustainable agriculture, preserving the environment and natural resources. In order to observe the influence of Rhizobia the agronomic effectiveness of cowpea strains was tested in two consecutive years compared with the mineral $\mathrm{N}$ fertilization. The experiments were carried out in different soils of the Brazilian Northeast (semiarid and rain forest region) which measured the effectiveness of rhizobia on grain yield. The results revealed the effectiveness of strain BR 3299 in the experiment that significantly increased the grain yield ( 3 times when $50 \mathrm{~kg} \mathrm{ha}^{-1}$ of $\mathrm{N}$, and 2 times when $80 \mathrm{~kg} \mathrm{ha}^{-1} \mathrm{~N}$ were used). The Rhizobia treatment promoted the grain yield (up to 1,600 kg ha ${ }^{-1}$ ), compared to application of $80 \mathrm{~kg} \mathrm{ha}^{-1}$ of $\mathrm{N}$. In general, all applied strains promoted the Brazilian Northeast average cowpea yield (300-400 kg ha-1).
\end{abstract}

Keywords: BNF, inoculants, residual power, sustainable agriculture, Vigna unguiculata .

Abbreviation: BR_Brazil; Conab_Conselho Nacional de Abastecimento in Brazil; FAO_Food and Agriculture Organization of the United Nations; INPA_Intituto Nacional de Pesquisa Agronomica; UFLA_Universidade Federal de Lavras.

\section{Introduction}

The cowpea (Vigna unguiculata L. Walp) is an annual legume of great social and economic importance, widely distributed in tropical regions of the Asian, African and American continents and is one of the major important source of protein for low-income populations (Moray et al., 2014; Xiong et al., 2016.). The production system is predominantly carried out by small and medium farmers that use genotypes for grain production. Currently, about 6 million tons of cowpea beans annually produced in 10 million hectares (FAO, 2010). The Brazilian Northeast is the region with highest cowpea production which corresponds to about $90 \%$ of the country yield obtained in the cultivated areas, which are predominantly performed for subsistence farming and characterized by low-technology system. The Brazilian soils for cowpea production are deficient in nutrients in general, especially N, and therefore, have low yield response (Conab, 2008, Saboya et al., 2013).

Practices that allow greater input of $\mathrm{N}$ are required to make the cowpea farming more productive and competitive.
Inoculation with effective $\mathrm{N}_{2}$-fixing rhizobia bacteria is an economic and environmentally beneficial option to promote the provision of $\mathrm{N}$ for plants. The symbiotic association of effective bacteria with cowpea is able to increase the grain yield and it may viable alternative to replace, partially or totally the application of mineral $\mathrm{N}$ fertilizers (Farias et al., 2016). However, in Brazil, the cowpea inoculation is not a common practice implemented in sustainable agriculture, mainly due to the lack of technical information for agronomic and economic viability. The main reason for this occurrence is the ability of cowpea to nodulate with a great variety of indigenous rhizobia, which often reduces the response to inoculation (Almeida et al., 2010, Chagas Junior et al., 2010). Therefore, the nodulation of cowpea with effective rhizobia may represent an important strategy to increase the interest to adopt the nitrogen fixation system.

In recent years, the evaluation of effective rhizobia on various legumes have been increased and are conducted in the Brazilian Northeast with the promising results obtained 
for various legumes as described by Calheiros et al. (2013, 2015) for calopo; Lima et al. (2012), for velvet beans, Torres Junior et al. (2014) and Santos et al. (2017) for peanuts, among others important species. However, few studies were carried out to evaluate the symbiotic effectiveness to increase cowpea yield by inoculation with specific strains of the Brazilian Northeast (Farias et al., 2016b).

The aim of the study was to evaluate the effectiveness of strains recommended for cowpea (cv. BR 17 Gurguéia) cultivated in soils of different Brazilian ecosystems (semiarid and rain forest) of the Northeast region, inoculated with Rhizobia strains recommended by Brazilian research Centers.

\section{Results and discussion}

\section{Efficiency of the strains}

The results of the experiments, conducted during two consecutive years at different sites showed similar responses. The results represented means of the two consecutive years and demonstrated that all used strains had been quite efficient (over 70\% of efficiency) compared to plants not inoculated and without addition of mineral $\mathrm{N}$ fertilizer (Fig 3 ). The data displayed the great importance of the inoculants for cowpea culture. It was observed that the strain BR 3299 has the best results of efficiency when applied in the experiment conducted in Recife (Pernambuco state) localized in the Rain Forest region with response of up to $350 \%$ increase comparing to the others effective strains (Figure 1).

\section{Effectiveness of the strains}

The effectiveness of the strains was calculated by comparing the results obtained by the control treatment (including mineral $\mathrm{N}$ fertilizer of 50 and $80 \mathrm{~kg} \mathrm{ha}^{-1}$ of $\mathrm{N}$ ), respectively (Fig 2). In reference for this parameter, the rhizobia strains showed very promising result for replacement of mineral Nfertilizer in cowpea crops. The BR3299 strain exhibited the best result, demonstrating efficiency over $300 \%$ when compared to control with $50 \mathrm{~kg} \mathrm{ha}^{-1} \mathrm{~N}$, and more than $200 \%$ increase compared to control including $80 \mathrm{~kg} \mathrm{ha}^{-1} \mathrm{~N}$ in the experiment conducted in Recife. The others strains showed similar behavior in the different regions and others localities.

\section{Grain yield}

Gualter et al. (2011) reported the efficiency of Rhizobia strains inoculated with cowpeas in the State of Maranhão, Brazil, and observed maximum yield $\left(679 \mathrm{~kg} \mathrm{ha}^{-1}\right)$ for the treatments with effective strains such as INPA 03-11B. Farias et al. (2016b) also evaluated the inoculation with rhizobia strains on cowpea in the state of Maranhão and Piaui and showed that UFLA 03-84 and INPA 03-11B strains had effectiveness of 61 and $69 \%$, respectively, compared to the treatment with application of $80 \mathrm{~kg} \mathrm{ha}^{-1} \mathrm{~N}$. The strain UFLA 03-153 was superior to the strains (UFLA 03-84 and INPA 03-11B) and showed that in the Maranhão state the highest grain yield was obtained with the inoculated treatments. In the State of Piaui, inoculation with UFLA 03-84 and INPA 03-11B, was produced yield of 797 to $1,621 \mathrm{~kg} \mathrm{ha}^{-1}$ in Dom Pedro: and 923 to $1,430 \mathrm{~kg} \mathrm{ha}^{-1}$ in São Luís, respectively. Marinho et al. (2014) obtained higher grain yield in the non-inoculated treatment and the results were similar to inoculation with the strains BR 3267, BR 3299T, and UFLA 03-84.

The inoculated treatments showed yield similar to the control treatment (not inoculated plants) and with application of mineral $\mathrm{N}$ fertilizer. However, the strains UFLA 03-84 and BR 3262 promoted an increase of 30 and $31 \%$ in grain yield, respectively, compared to the control treatment.

In Teresina and Juazeiro regions, where a frequent rainfall is not happened, the grain yield was higher than $1,200 \mathrm{~kg} \mathrm{ha}^{-1}$ (Fig 3). The results are not statistically different from those obtained in Recife experiment, where the rainfall was more abundant and frequent. However, the yield was lower and cowpea did not express symbiotic and productive potential, although the grain yield, were up than the national average (300 kg ha ${ }^{-1}$ ). The experiment results in Recife showed that the strain BR 3299 contributed to a yield equivalent to 1,648 $\mathrm{kg} \mathrm{ha}^{-1}$ and was superior to the treatment with mineral $\mathrm{N}$ fertilizer $\left(80 \mathrm{~kg} \mathrm{ha}^{-1}\right)$ demonstrating that in this locality the best cowpea yield and effectiveness of the inoculation with recommended strains is achieved.

It is important to note that the data for bean crop yield provided by the National Company of Statistic in Agriculture included the yield for common bean's (Phaseolus vulgaris) and for cowpea (Vigna unguiculata). Recent studies show higher cowpea yield when inoculants or fertilizers are applied (Farias et al., 2016a, Farias et al., 2016b).

The BNF is able to provide the necessary $\mathrm{N}$ for cowpea, following of a descending order by the soil and fertilizers (Brito et al., 2009). Oliveira (2003), cultivated cowpea (cv. IPA 206), in an irrigation system in micro-region of Areias (Paraiba state) and reported the grain yield of about $3.6 \mathrm{t} \mathrm{ha}^{-1}$ when compared to application of mineral $\mathrm{N}$ fertilizer $(56.0 \mathrm{~kg}$ $\mathrm{ha}^{-1}$ of $\mathrm{N}$ ) to the soil and $3.4 \mathrm{tha}^{-1}$ when fertilized with 59.0 $\mathrm{kg} \mathrm{ha}^{-1}$ of $\mathrm{N}$, in foliar application.

The corresponding analysis for the treatments with and without $\mathrm{N}$ and inoculated with effective strains (Fig 4), showed the influence of the treatments with mineral $\mathrm{N}$ fertilizer (50 and $80 \mathrm{~kg} \mathrm{ha}^{-1}$ ) with a positive correlation between both parameters. A negative correlation was observed with all the used strains in the control treatment (not inoculated with rhizobia and without $\mathrm{N}$ fertilization). The INPA 03-11B, UFLA 3-84, BR 3262 and BR 3267 strains grouped in a similar way, showed a positive correlation between the inoculated treatments and a negative correlation with the treatments with and without mineral $\mathrm{N}$-fertilization. The strain BR 3299 did not display a positive correlation with the other treatments (inoculants and controls).

The different groups between the strains and mineral $\mathrm{N}$ fertilization indicate that the application of fertilizers negatively influenced the ability of rhizobia to provide $\mathrm{N}$ for cowpea plants. It is known that $\mathrm{N}$ fixing legumes usually increase the amount of $\mathrm{N}$ in the soil-plant system, but when the amount of $\mathrm{N}$ in the soil is increased the addition of $\mathrm{N}$ via NFB decreases.

\section{Materials and methods}

\section{Plant and strain characteristics}

Cowpea seeds (cv. BR 17 Gurguéia) were surface-sterilized in $70 \%$ ethyl alcohol for $1 \mathrm{~min}$, followed by immersion in $\mathrm{HgCl}_{2}$ (1:500) for $0.5 \mathrm{~min}$ and washed six times with sterile water. The seeds were mixed with a sugar solution $(10 \% \mathrm{w} \mathrm{v}$ $\left.{ }^{1}\right)$ in the proportion of $6 \mathrm{~mL} \mathrm{~kg}^{-1}$ and inoculated in accordance with Howieson (2015).

The strains effectiveness were studied in experiments conducted in the Brazilian semiarid region located in the Juazeiro (Bahia), Petrolina (Pernambuco) and in the District of Esperance (Paraiba), and the specific characteristics and 
Table 1. Local, physiographic zone, coordinates and annual precipitation of the different localities.

\begin{tabular}{|c|c|c|c|}
\hline Local & Physiographic Zone & Coordinates & Annual precipitation (mm/year) \\
\hline Recife (PE) & Rain Forest & $8^{\circ} 20^{\prime} 57^{\prime \prime} \mathrm{S} \quad 34^{\circ} 56^{\prime} 49^{\prime \prime} \mathrm{W}$ & $\begin{array}{l}500 \text { a } 2000 \text {, with two well defined } \\
\text { seasons: rainy (Mar-Aug); dry (Sept- } \\
\text { April) }\end{array}$ \\
\hline Esperança (PB) & Semiarid & $7^{\circ} 1^{\prime} 0.8^{\prime \prime S} 35^{\circ} 52^{\prime} 50.3^{\prime \prime} \mathrm{W}$ & $\begin{array}{l}650 \text { a } 700 \text {, with two well defined seasons: } \\
\text { rainy season (Feb-June); dry (April- Dec) }\end{array}$ \\
\hline Petrolina (PE) & Semiarid & $9^{\circ} 23^{\prime} 55^{\prime \prime} \mathrm{S} 40^{\circ} 30^{\prime} 03^{\prime \prime} \mathrm{W}$ & $\begin{array}{l}500 \text { a } 600 \text {, with two well defined seasons: } \\
\text { rainy (Jan-May); dry (April-Dec) }\end{array}$ \\
\hline Juazeiro (BA) & Semiarid & $9^{\circ} 24^{\prime} 42^{\prime \prime S ~ S ~} 40^{\circ} 29^{\prime} 55^{\prime \prime} \mathrm{W}$ & $\begin{array}{l}500 \text { a } 600 \text {, with two well defined seasons: } \\
\text { rainy (Jan-May); dry (April- Dec) }\end{array}$ \\
\hline Teresina (PI) & Semiarid & $5^{\circ} 05^{\prime} 21^{\prime \prime} \mathrm{S} 42^{\circ} 48^{\prime} 07^{\prime \prime} \mathrm{W}$ & $\begin{array}{l}400 \text { a 500, with two well defined seasons: rainy } \\
\text { (Dec-May); dry (June-Nov) }\end{array}$ \\
\hline
\end{tabular}

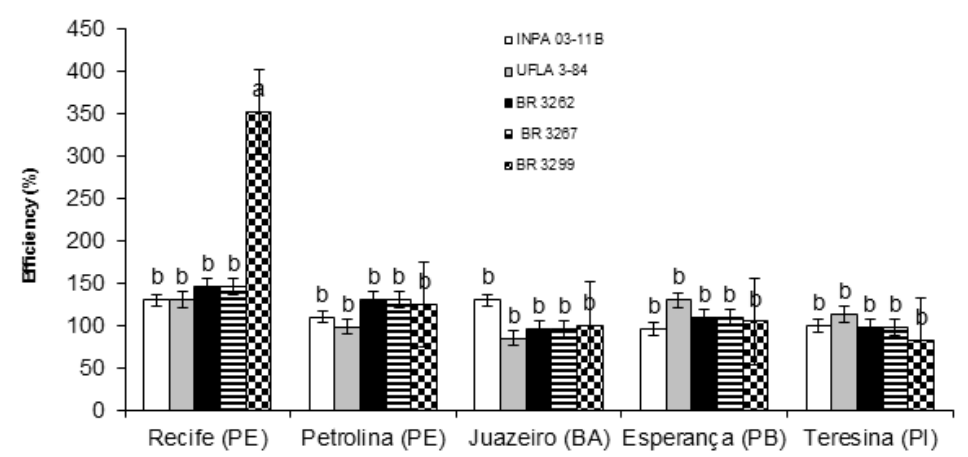

Fig 1. Efficiency of the inoculation treatments with recommended strains in the different localities.

Table 2. Chemical analysis of soils.

\begin{tabular}{|c|c|c|c|c|c|c|c|c|}
\hline Locality & $\begin{array}{l}\mathrm{pH} \\
\left(\mathrm{H}_{2} \mathrm{O}\right)\end{array}$ & $\begin{array}{l}\text { Total C } \\
\mathrm{g} \mathrm{kg}^{-1}\end{array}$ & $\begin{array}{r}\text { Available } \\
\mathrm{m}\end{array}$ & & $\begin{array}{l}\mathrm{Ca} \\
---\mathrm{cmo}\end{array}$ & & $\mathrm{Al}$ & $\mathrm{H}+\mathrm{Al}$ \\
\hline Recife (PE) & 5.0 & 0.20 & 14.2 & 14.8 & 1.1 & 0.3 & 0.8 & 1.67 \\
\hline Petrolina (PE) & 6.3 & 0.51 & 11.9 & 13.2 & 2.0 & 0.4 & 0.0 & 0.66 \\
\hline Juazeiro (BA) & 6.8 & 0.42 & 44.6 & 14.4 & 20.4 & 5.6 & 0.0 & 4.62 \\
\hline Esperança (PB) & 5.7 & 0.70 & 89.8 & 27.6 & 2.14 & 0.9 & 0.0 & 3.52 \\
\hline Teresina (PI) & 5.4 & 0.62 & 37.8 & 20.5 & 2.36 & 1.7 & 0.4 & 2.43 \\
\hline
\end{tabular}
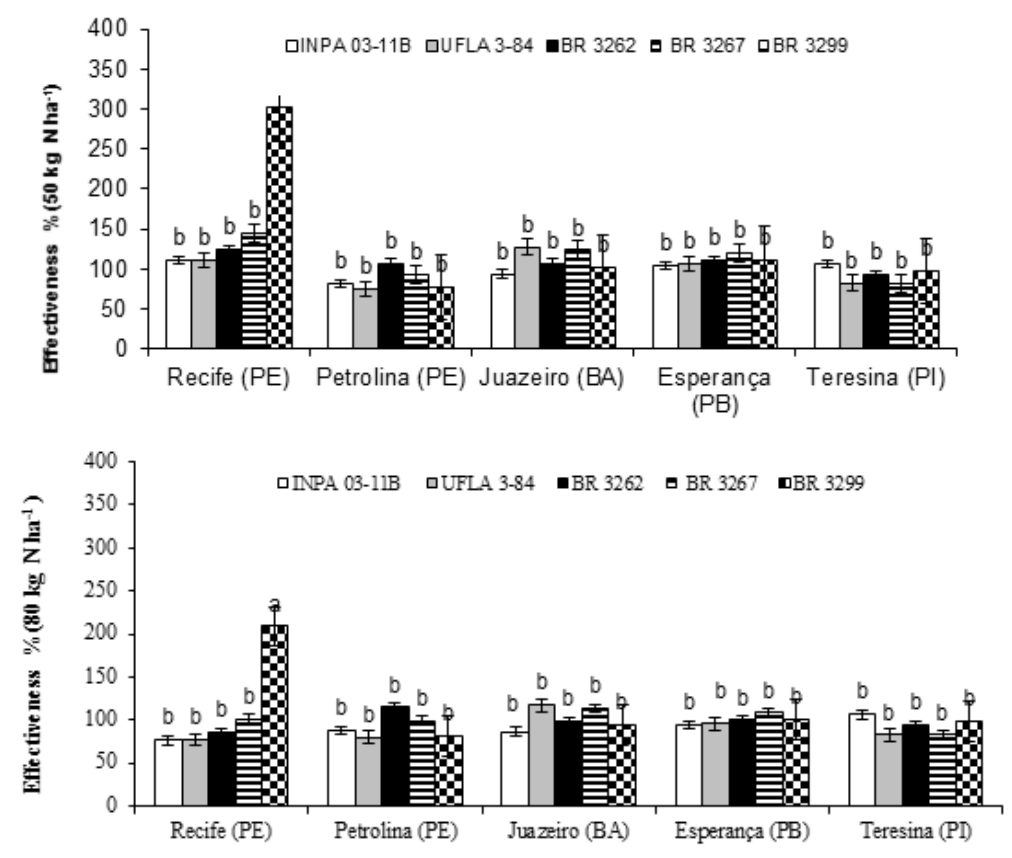

Fig 2. Effectiveness of cowpea inoculated with the recommended strains (INPA 03-11B; UFLA 3-84; BR 3262; BR 3267 and BR 3299), in the different localities, compared to control with $50 \mathrm{~kg} \mathrm{~N} \mathrm{ha}^{-1}$ (A) and $80 \mathrm{~kg} \mathrm{~N} \mathrm{ha}^{-1}$ (B). 
Table 3. Characteristics of the Rhizobia strains used in the experiments.

\begin{tabular}{lccccc}
\hline Rhizobia strains & \multirow{2}{*}{ Brazilian ecosystem } & \multicolumn{2}{c}{ Strains characteristics } & \multirow{2}{*}{ Rhizobia species } \\
\cline { 3 - 4 } & Amazônia & Slow & Alkaline & White & Bradyrhizobium sp. \\
INPA 03-11B & Amazônia & Slow & Alkaline & White & Bradyrhizobium sp. \\
UFLA 3-84 & Caatinga & Slow & Alkaline & White & Bradyrhizobium sp. \\
BR 3267 & Cerrado & Slow & Neutral & White & Bradyrhizobium sp. \\
BR 3262 & Caatinga & Fast & Alkaline & White & Microvirga vignae \\
BR 3299 & & & &
\end{tabular}

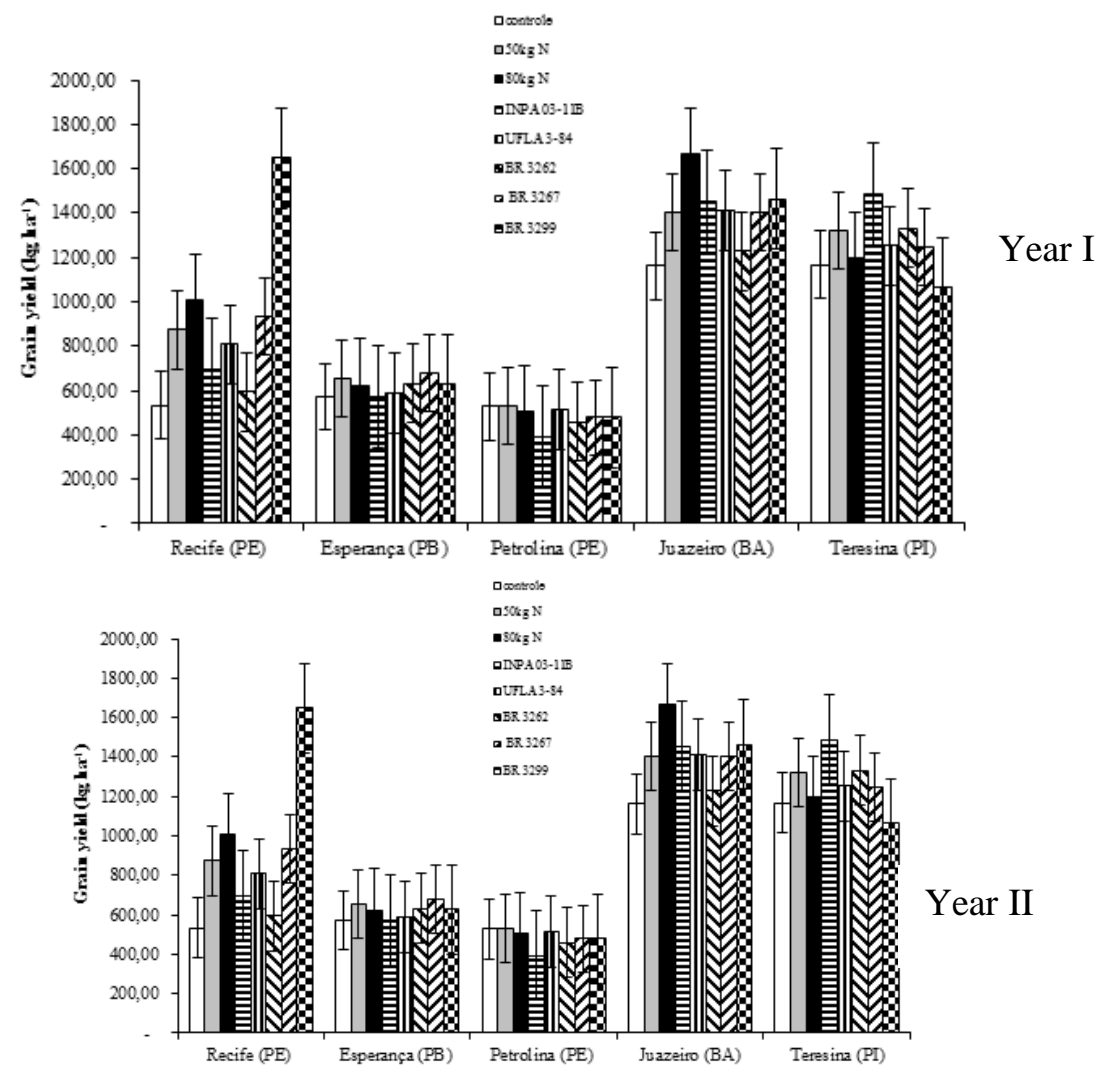

Fig 3. Cowpea grain yield $\left(\mathrm{kg} \mathrm{ha}^{-1}\right)$, inoculated with recommended strains INPA 03-11B; UFLA 3-84; BR 3262; BR 3267 and BR 3299 , in the different localities, in the consecutive years.

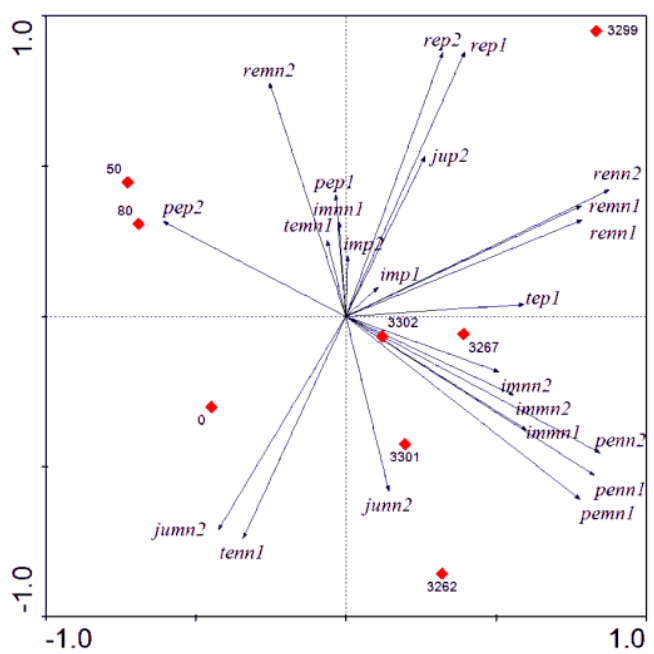

Fig 4. Multivariate analysis showing the correspondence of localities and Rhizobia strains inoculated. 

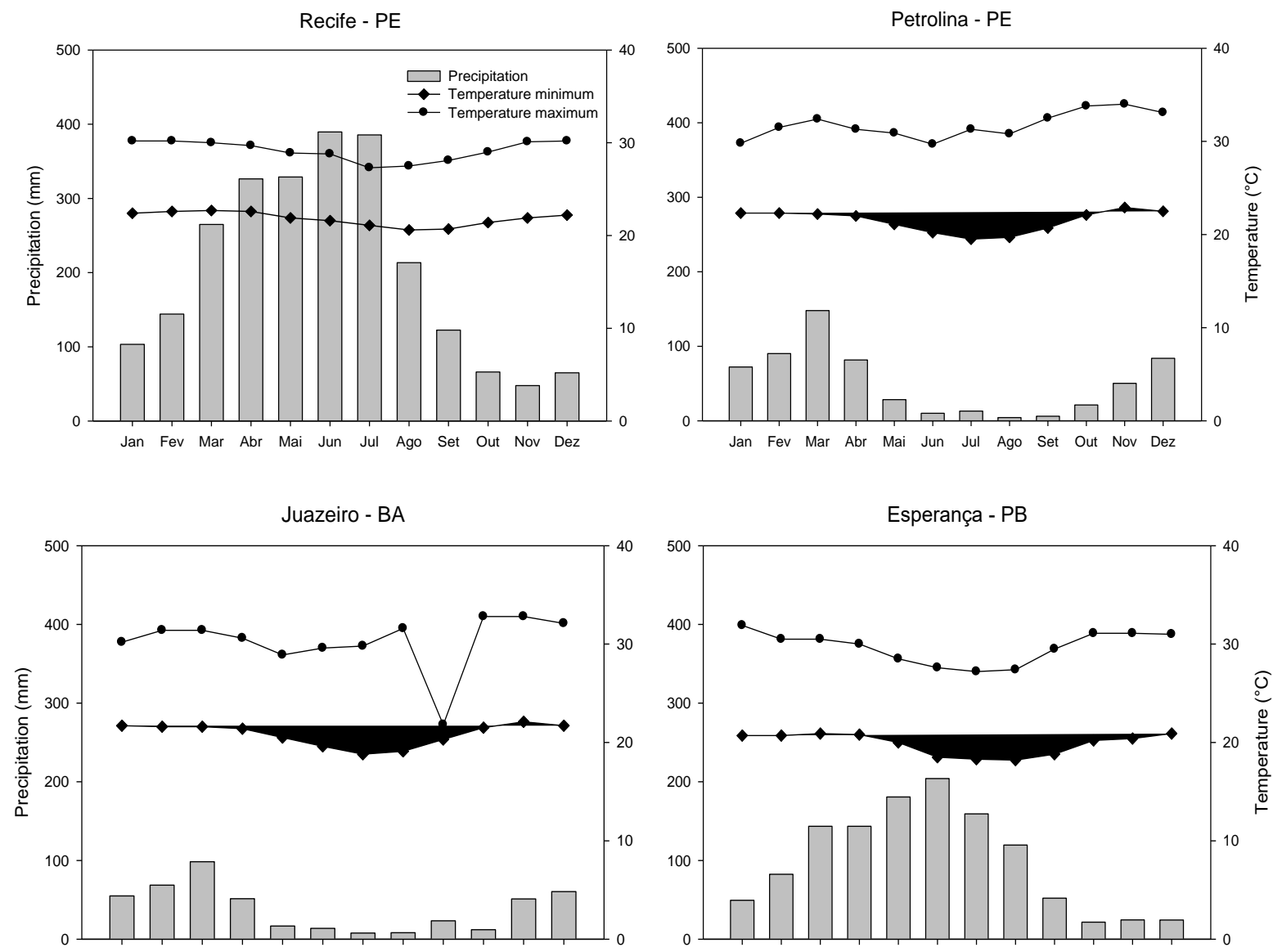

Jan Fev Mar Abr Mai Jun Jul Ago Set Out Nov Dez

Jan Fev Mar Abr Mai Jun Jul Ago Set Out Nov Dez

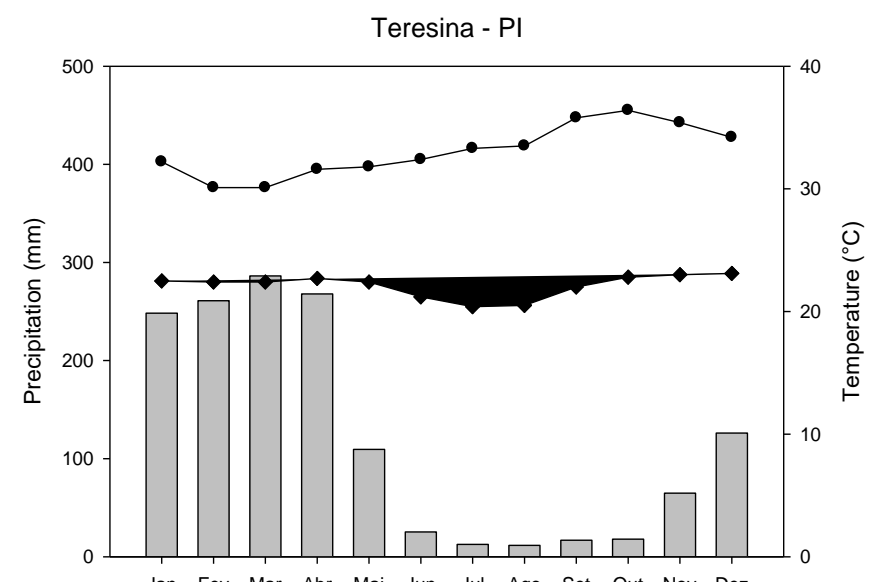

Fig 5. Annual precipitation with temperature (minimum and maximum) of the different localities.

climate of the Rain Forest Zone (Recife, Pernambuco) and (Teresina, Piaui), are described in Fig 5.

\section{Site and soil description}

The study was conducted throughout interstate interaction groups for two consecutive years. The followed institutions localized in the cowpea producing areas of the Brazilian Northeast have participated in the integrate project: (Universidade Federal Rural de Pernambuco, Universidade Federal de Pernambuco, Universidade do Estado da Bahia,
Universidade Estadual da Paraiba and Embrapa Meio Norte), coordinated by the Embrapa Agrobiologia (Seropédica, Rio de Janeiro)

The semiarid region is characterized by high temperatures with very intense rainy season but in short period ( 4 to 5 months), and sometimes with no rain during the dry season. In this region, the agricultural practice is possible through irrigation techniques, as observed in the Fruit Agricultural Polo of Petrolina (PE) and Juazeiro (BA), where the largest centers of irrigated fruit production in the Brazilian Northeast resides. The Rain Forest Zone is close to the coastal 
tablelands, where the rains are very abundant and better distributed throughout the year, with medium and high temperatures (Table 1).

In the different localities, three months before the conduction of the experiments, soil samples collected at 0-30 $\mathrm{cm}$ depth and submitted to the chemical analysis (Table 2). When necessary, the soil acidity was neutralized with liming (dolomitic lime) applied to increase the base saturation to $60 \%$.

\section{Experimental conditions}

In the field experiment the treatment with fertilizer addition were added at the recommended rate for cowpea (IPA, 2008) and with the double of recommended rate, applied at the planting date, 15 days after planting. During the experimental period the soil moisture was maintained near field holding capacity by daily application of water.

The plants were cultivated in lines and the seeds planted manually, after the seeds inoculation with the respective treatments. At planting date, the plants were fertilized with $\mathrm{P}$ and $\mathrm{K}$ applying $20 \mathrm{~kg} \mathrm{ha}^{-1}$ of $\mathrm{K}_{2} \mathrm{O}$ and $60 \mathrm{~kg} \mathrm{ha}^{-1}$ of $\mathrm{P}_{2} \mathrm{O}_{5}$, based on soil analysis performed prior to the experimental conduction. The phosphorus and potassium sources were triple superphosphate and potassium chloride, respectively.

\section{Experimental design}

The experiments followed the same experimental design in randomized block with 8 treatments that consisted of peat inoculant with strains: 1) INPA 3-11B; 2) UFLA 3-84; 3) BR 3262; 4) BR 3267 and 5) BR 3299, whose characteristics are shown in Table 3. Control treatments were included and corresponded to treatments non-inoculated with rhizobia: 6) without $\mathrm{N}$ fertilizer; 7) with mineral $\mathrm{N}$ fertilization (urea 40 $\mathrm{kg} \mathrm{ha}^{-1}$ ); 8) with $\mathrm{N}$ fertilization (urea $80 \mathrm{~kg} \mathrm{ha}^{-1}$ ), with $\mathrm{N}$ applied in two times $\left(40 \mathrm{~kg} \mathrm{ha}^{-1}\right.$ at planting date, and $40 \mathrm{~kg}$ $\mathrm{ha}^{-1}, 15$ days after planting).

In different regions, the experiments performed in 32 plots. Each plot contained four rows with $6 \mathrm{~m}$ long each, spaced 1.0 $\mathrm{m}$ between rows. Four seeds per hole were planted and two weeks after emergence two seedlings were maintained. The useful area for each plot $\left(10 \mathrm{~m}^{2}\right)$ corresponded to the two central rows, dispensing $0.5 \mathrm{~m}$ of the row sides $(5 \mathrm{~m} \times 2 \mathrm{~m})$. During plant development in the different localities, the experiments were maintained free from weeds and controlled insects and diseases.

\section{Plant determinations}

50 days after emergence (DAE), ten plants of the useful area were randomly harvested and the shoots dried at $65-70{ }^{\circ} \mathrm{C}$ for $72 \mathrm{~h}$ to obtain the dry matter yield, and the data used to determine the agronomic efficiency and effectiveness of the rhizobia strains. The efficiency was calculated by the ratio of the total $\mathrm{N}$ in shoot dry biomass of the inoculated treatment to the total $\mathrm{N}$ in shoot dry biomass of the control treatment (non-inoculated and without mineral $\mathrm{N}$ fertilization). The effectiveness was calculated using the ratio of the total $\mathrm{N}$ in shoot dry biomass of the inoculated treatments to the total $\mathrm{N}$ in shoot dry biomass of the treatment non-inoculated with mineral $\mathrm{N}$ addition). For each treatment, the plants of the useful area were harvested and the grain yield (humidity adjusted to $13 \%$ ), shoot dry weight (DW) dried at $65-70{ }^{\circ} \mathrm{C}$ for $72 \mathrm{~h}$, and total $\mathrm{N}$ in the shoots were determined according to the Embrapa (2009).

\section{Statistical analysis}

The results of efficiency and effectiveness of the strains and the grain yield were subjected to the analysis of variance and the $\mathrm{F}$ test. The significance of means was compared by the Tukey test ( $\mathrm{p} \leq 0.05)$, using the software Sisvar, version 4.0 (Ferreira, 2008). Then a multivariate analysis using the software Statistica 8.0 was conducted.

\section{Conclusion}

The cowpea grain yield obtained in this experiment was superior to the national average $\left(300 \mathrm{~kg} \mathrm{ha}^{-1}\right)$ and the tested strains showed high efficiency and effectiveness in $\mathrm{N}_{2}$ fixation in all experiment localities, regardless of environment classification and precipitation. The strain BR 3299 applied in Recife showed the highest efficiency and effectiveness. The strains showed high positive correlation between them, and a negative correlation with the $\mathrm{N}-$ fertilizer treatments.

\section{Acknowledgments}

The authors thank to MCT/CNPq, DECIT/MS, Biotechnology Sector (CT-Biotecnologia) and Health Fund (CT-Saude) for funding this project under the terms of Renorbio and for granting scholarships for Technological and Industrial initiation. Also, the authors are in debt to the Conselho Nacional de Desenvolvimento Científico e Tecnológico - CNPq and to the Fundação Apoio e tecnologia do Estado de Pernambuco - FACEPE, for the scholarships.

\section{References}

Almeida ALG, Alcantara RMCM, Nóbrega RSA, Nóbrega JCA, Leite LFC, Silva JAL (2010) Yield and nodulation of cowpea (Vigna unguiculata L Walp.) inoculated with rhizobia strains. Rev Bras Ci Agr. 5: 364-369.

Brito MDP, Muraoka T, Silva EC (2009) Marcha de absorção do nitrogênio do solo, do fertilizante e da fixação simbiótica em feijão-caupi (Vigna unguiculata L Walp.) e feijão-comum (Phaseolus vulgaris L.) determinada com uso de 15N. Rev Bras Ci Solo. 33: 895-905.

Calheiros AS, Lira Junior MA, Soares DM, Figueiredo MVB (2013) Symbiotic capability of calopo rhizobia from an agrisoil with different crops in Pernambuco. Rev Bras Ci Solo. 37: 869-876.

Calheiros AS, Lira Junior, MA, Santos MVF, Lyra MCCP (2015) Symbiotic effectiveness and competitiveness of calopo rhizobial isolates in an argisol under three vegetation covers in the dry forest zone of Pernambuco. Rev Bras Ci Solo. 39: 367-376.

Chagas Júnior AF, Rahmeier W, Fidelis RR, Santos GR, Chagas LFB (2010) Eficiência agronômica de estirpes de rizóbio inoculadas em feijão-caupi no Cerrado, Gurupi-TO. Rev Ci Agron. 41: 709-714.

Conab-Companhia Nacional de Abastecimento. Acompanhamento da safra brasileira de grãos: primeiro levantamento, outubro de 2008 (2008) Brasília: Conab, http://www.conab.gov.br/conabweb/download/safra/estudo _safra.pdfDisponível na Internet: Accessed 8 April 2014.

Embrapa - Empresa Brasileira de Pesquisa Agropecuária (2009) Manual de métodos de análises de solos, plantas e fertilizantes. Rio de Janeiro. p.627.

Farias TP, Araújo ARAD, Soares BL, Moreira FMS (2016a) Rhizobia inoculation and liming increase cowpea productivity in Maranhão State. Acta Sci. 38: 387-395. 
Farias TP, Soares BL, Araújo ARAD, Moreira FMS (2016b) Symbiotic efficiency of rhizobia strains with cowpea in southern Maranhão. Rev Caatinga. 29: 611-618.

Ferreira DF (2008) Sisvar: um programa para análises e ensino de estatística. Rev Ci Symp 6: 36-41.

Food and Agriculture Organization of the United Nations, FAO (2010) Crops cowpeas. http://faostat.fao.org/site/567/DesktopDefault.aspx?PageID $=567 \#$ \#ancor. Accessed 10 October 2015 .

Gualter RMR, Boddey RM, Rumjanek NG; Freitas ACR, Xavier GR (2011) Eficiência agronômica de estirpes de rizóbio em feijão-caupi cultivado na região da PréAmazônia maranhense. Pesq Agropec Bras. 46: 303-308.

Howieson JG Dilworth MJ (2015) Working with rhizobia. Australian Centre for International Agricultural Research, Canberra.

IPA - Instituto de Pesquisa de Pernambuco (2008) Recomendação de adubação para o estado de Pernambuco. Recife, Brazil.

Lima AA, Fernandes Júnior PI, Passos SR, Paulo FS (2012) Diversidade e capacidade simbiótica de rizóbios isolados de nódulos de Mucuna-Cinza e Mucuna-Anã. Rev Bras Ci Solo. 36: 337-348.
Marinho RCN, Nóbrega RSA, Zilli JE, Xavier GR, Santos CAF, Aidar ST, Martins LMV, Fernandes Júnior PI (2014) Field performance of new cowpea cultivars inoculated with efficient nitrogen-fixing rhizobial strains in the Brazilian Semiarid. Pesq Agropec Bras. 49: 395-402.

Moray C, Game ET, Maxted N (2014) Prioritising in situ conservation of crop resources: A case study of African cowpea (Vigna unguiculata). Sci Rep. 4: 1-5.

Saboya RCC, Borges PRS, Saboya LMF, Monteiro FPR, Souza SEA, Santos AF, Santos ER (2013) Response of cowpea to inoculation with nitrogen-fixing strains in Gurupi-Tocantins State. J Biotec Biod. 4: 40-48.

Santos CERS, Silva VSG, Freitas ADS, da Silva, AF, Bezerra, RV, Silva JF (2017) Prospecting of efficient rhizobia for peanut inoculation in a Planosol under different vegetation covers. Afr J Microbiol Res. 11: 123131.

Torres Júnior CV, Leite J, Santos CERS, Fernandes Junior PI. Zilli, JE, Rumjanek, NG, Xavier GR (2014) Diversity and symbiotic performance of peanut rhizobia from Southeast region of Brazil. Afr J Microbiol Res 8: 566-577.

Xiong H, Shi A, Mou B, Qin J, Motes D, Lu W, Wu D. (2016). Genetic diversity and population structure of cowpea (Vigna unguiculata L. Walp). PLoS One. 11(8) e0160941. Doi: 10.1371/journal.ponde.0160941. 